\title{
When hummingbirds are the thieves: visitation effect on the reproduction of Neotropical snowbell Styrax ferrugineus Nees \& Mart (Styracaceae)
}

\author{
Pietro Kiyoshi Maruyama ${ }^{1,2}$, Luciana Nascimento Custódio ${ }^{1}$ and Paulo Eugênio Oliveira
}

Recebido em 24/04/2011. Aceito em 16/11/2011

\section{RESUMO}

(Quando os beija-flores são os ladrões: efeito da visitação na reprodução de uma planta Neotropical Styrax ferrugineus Nees \& Mart (Styracaceae)). O espectro de visitantes florais associados a uma planta é frequentemente maior que o esperado pelo conceito tradicional de síndromes florais e o papel desses visitantes inesperados tem recebido mais atenção. Os beija-flores freqüentemente visitam flores com síndromes florais distintas, especialmente em alguns ecossistemas pobre em flores ornitófilas como o Cerrado. Investigamos aqui o efeito das visitas de beija-flores na reprodução de Styrax ferrugineus, uma espécie melitófila. As flores foram visitadas por diferentes grupos de insetos e as visitas por beija-flores foram frequentes, especialmente no início das manhãs quando a disponibilidade de néctar foi maior. Os parâmetros de néctar variaram consideravelmente durante a antese, provavelmente afetados pela variação da temperatura durante o dia. Experimentos de exclusão de beija-flores não mostraram efeito sobre a produção de frutos. A incapacidade dos beija-flores em esgotar todo néctar produzido pela planta e a existência de outro recurso floral (pólen) para o polinizador principal (grandes abelhas) são apontadas como razões possíveis para a ausência desse efeito. Embora não tenha sido observado efeito sobre a produção de frutos, o uso de flores não ornitófilas deve ser importante para os beija-flores que são consumidores especializados de néctar.

Palavras-chave: Cerrado, dinâmica de néctar, ladrões de néctar, síndromes de polinização

\begin{abstract}
(When hummingbirds are the thieves: visitation effect on the reproduction of neotropical snowbell Styrax ferrugineus Nees \& Mart (Styracaceae)). The spectrum of floral visitors associated with a particular plant is frequently larger than predicted by the traditional concept of floral syndromes and the role that unpredicted visitors play in plant reproduction deserves attention. Hummingbirds are frequently recorded visiting flowers with distinct floral syndromes, especially in some hummingbird flower poor ecosystem such as the Cerrado. In this study we investigated the effect of frequent hummingbird visits on the reproduction of melittophilous Styrax ferrugineus. The flowers were visited by many different insect groups and visits by hummingbirds were frequent, especially early in the morning when nectar availability was higher. Nectar parameters varied considerably during the flower life span, and was probably affected by the temperature variation during the day. Hummingbird exclusion experiments showed no effect in the fruit-set of the plant. The inability of hummingbirds to deplete all of the nectar produced in this mass-flowering plant, and the existence of another resource (pollen) for the primary pollinator (large bees), are possible reasons why there was no perceptible hindrance of plant reproduction by the hummingbirds. Although no effect in the fruit-set was observed, the use of non-ornithophilous flowers must be important for hummingbirds, which are specialized nectar consumers.
\end{abstract}

Key words: Cerrado, nectar dynamics, nectar thieves, pollination syndromes

1 Universidade Federal de Uberlândia, Instituto de Biologia, Uberlândia, MG, Brazil

2 Author for correspondence: pietrokiyoshi@yahoo.com.br 


\section{Introduction}

The sets of flower characteristics that define pollination syndromes are easily recognizable in many plant species. The frequent convergence of flower features shared among species presumably pollinated by the same pollinator group support the concept of the flower syndrome as an adaptation to specific pollinators (Johnson \& Steiner 2000). However, the spectrum of flower visitors associated with a given plant is frequently larger than what would be expected based in the concept of pollination syndromes (Waser et al. 1996), and the role these "unpredicted" visitors play in plant reproduction has been studied (Roubik 1982; Lara \& Ornelas 2001; Muchhala 2006; Fumero-Cabán \& MeléndezAckerman 2007; Maruyama et al. 2010).

Hummingbirds are considered the most specialized nectar feeding birds (Stiles 1981) and many plants present a strict association with them, which is expressed by a set of flower characteristics that enhance the efficiency of pollination (Castellanos et al. 2004). In spite of the close relationship hummingbirds and some plants often exhibit, these birds are commonly recorded visiting flowers that presumably are adapted to be pollinated by another group of animals, such as bees and bats, revealing their opportunistic foraging behavior (e.g. Oliveira \& Gibbs 1994; Rojas \& Ribon 1997; Araujo \& Sazima 2003; Muchhala 2006). Hummingbirds frequently act as "nectar thieves", which, in contrast to "nectar robbers", do not damage flowers in order to steal nectar (Inouye 1980), and this opportunistic visiting of flowers could be crucial for supplying birds with energy for their activities.

Despite these records, the effects of hummingbird visits on non-ornithophilous plant reproduction are seldom investigated. Considering that interactions between hummingbirds and non-ornithophilous plants are common, we investigated the pollination ecology of a non-ornithophilous plant that receives frequent hummingbird visits, and looked for the possible effect of the hummingbirds on the fruit-set of the plant.

\section{Material and methods}

Styrax L. is the largest genus within Styracaceae, comprising about 130 species of trees and shrubs distributed in Asia, the Americas and the Mediterranean (Fritsch 1999). Their flowers are frequently pollinated by Bombus and Apis bees, but butterflies (Papilionidae), flies (Syrphidae), hawkmoths (Sphingidae), wasps and other groups of bees have been recorded visiting the flowers and collecting both nectar and pollen as floral rewards (Huang et al. 2003). In the Cerrado biome, three species of Styrax are found, and $S$. ferrugineus Nees \& Mart is the most common species in the central portion of this biome (Nakajima \& Monteiro 1986; Saraiva et al. 1988). This species presents white, reflexed petals united at the base, forming a short corolla tube (around $5 \mathrm{~mm}$ ), and ten exerted yellow stamens with introrse anthers that are positioned around the pistil (Saraiva et al. 1988). From the bottom of the nectar chamber to the stigma on top of the pistil, its flowers measure 18-20 mm (Saraiva et al. 1988).

The study was carried out from 2007 to 2010, mostly from May to July when S. ferrugineus flowers in the private reserve of Clube de Caça e Pesca Itororó de Uberlândia (CCPIU - $18^{\circ} 60^{\prime} \mathrm{S}, 48^{\circ} 18^{\prime} \mathrm{W}$ ) in the state of Minas Gerais, Brazil. In this area, which is approximately 400ha of natural vegetation, the most common plant physiognomy is typical cerrado, a savanna type vegetation with scattered trees where S. ferrugineus mostly occurs. The climate in the area is markedly seasonal (Aw type, according to Köppen 1948), with a dry, cold winter (from May to September) and a wet, hot summer (from October to April).

We recorded floral attributes, such as flower opening time, odor and nectar production, in the field. To determine the flower opening time, we marked 10 flowers per individual on six plants, and followed these flowers from dawn on. Nectar availability was evaluated by measuring nectar production and standing crop at different time intervals during the day. We took all samples from flowers that had opened by 07:00 as a standard, because some flowers opened later during the day (but most flowers opened early in the morning, see results). Freshly opened flowers were easily identified by their anthers that had a bright, intense yellow color. We measured accumulated nectar at 07:00-08:00, 10:00-11:00, 16:00-17:00 on the first day and again at 07:00-08:00 on the second day of the life span of the flowers. Flowers sampled at one interval were not sampled at another. Nectar volume was measured by extracting it with glass micropipettes and sugar concentration measured with a hand refractometer (0-50\%, Eclipse $\left.{ }^{\circledR}, \mathrm{UK}\right)$. Sugar concentration higher than $50 \%$ was estimated by diluting nectar with same volume of distillated water and then doubling the result. The values of nectar volume and concentration were used to estimate the amount of sugar present in the flowers, which was based on Galetto \& Bernadello (2005). In order to estimate the nectar production and standing crop, we took measurements of flowers that were isolated from visitors with nylon mesh bags and exposed flowers, respectively. At least forty isolated and exposed flowers for each time interval were sampled from 10 individuals, and the sampling was never more than five flowers for each individual at given time interval and category. The parameters of nectar (volume, concentration and sugar content) were compared among the time intervals using ANOVA, after $\log _{10}(\mathrm{x}+1)$ transformation and a post hoc Tukey test (Zar 1999).

The composition of flower visitors was determined with focal plant observation of nine individuals of $S$. ferrugineus. Observations were made from 07:00 to 18:00, with observation sessions of one hour. Each time interval of one hour was sampled three times, never repeating the same time interval for each individual, which totaled 33 
hours of observation. During each observation session we registered the visitation frequency of each visitor group: large bees (at least $2 \mathrm{~cm}$, approximately the size of the flowers), wasps (idem), lepidopterans (butterflies and moths), small insects (insects smaller than the flower, including bees such as Trigona spp., Syrphidae flies and other insects of similar size) and hummingbirds. For two specific groups we also conducted qualitative observations in order to characterize their behavior in the flowers: large bees, which are considered the legitimate pollinator of $S$. ferrugineus (see Saraiva et al. 1988), and hummingbirds. The parameters observed were: the number of flowers probed each visit, the duration of each visit, contact with reproductive structures of the flower and agonistic interaction. Whenever possible, insects were captured for identification. Hummingbirds were identified in the field, using binoculars. To assess whether the visitation frequency of each group of floral visitors was different during the day we used one-way ANOVA considering the time interval as a factor. Time intervals considered were: 07:01-09:00, 09:01-11:00, 11:01-14:00, 14:01-16:00 and 16:01-18:00. Tukey's multiple comparison test was performed when the null hypothesis was rejected by ANOVA (Zar 1999). The flower visitor data were $\log _{10}$ transformed before the analyses (Zar 1999). The number of flowers probed and the duration of visits were compared between large bees and hummingbirds by the Student's $t$ test. The duration of visits was $\log _{10}$ transformed before the analysis (Zar 1999).

The flowering phenology was quantified in an area of tha where we recorded all flowering individuals of $S$. ferrugineus fortnightly from March 2009 to February 2010. For each individual we counted the number of open flowers. The plant reproductive system was evaluated by hand pollination experiments carried out on eight individuals. Plants chosen for the pollination experiment produced tens of flowers per day and eight individuals were sufficient to perform all treatments for all individuals. For the experiment, flowers were kept isolated using nylon mesh bags, including the pollen donor flowers. Four different treatments were performed on the flowers: cross-pollination (flowers of different individuals), self-pollination (different flowers within the same individual), spontaneous self-pollination (flowers kept isolated by nylon mesh bags) and agamospermy (previously emasculated flowers kept isolated). Each treatment was performed on all eight individuals, with at least five flowers per treatment per individual. Flowers were also marked and kept exposed to pollinators as a control, in order to estimate the natural pollination success. Fruit development was followed to evaluate pollination treatment success.

In order to estimate the effect of hummingbird visits on plant reproduction we conducted an exclusion experiment using white blotched, wire mesh $(6 \mathrm{x} 8 \mathrm{~cm})$ cages. For each plant we marked a control and experimental branch, always trying to use the most distant pair on the plant. Each branch produced more than 100 flowers during the flowering season. The wire cage on the experimental branch hindered hummingbird visits but not other visitors (observed previously and during the experiment). At least once a week during the flowering period, we marked open flowers for each branch, always marking the same number of flowers in the control and experimental branch of each individual for each day. At least 30 flowers per category for each individual were marked. We marked seven individuals in 2009 and another seven individuals in 2010, but since results did not differ among years we grouped the results for the analysis. To verify if hummingbirds had some effect on the overall reproduction of the plant, the mean fruit-set of marked flowers was compared using a paired Student's $t$ test between the control and experimental branches (Zar 1999).

\section{Results}

Styrax ferrugineus flowers opened mostly in the beginning of the morning, between 06:00 and 07:00 (66.5 $\pm 11.2 \%)$, but some flowers opened later during the day. The flowers remained open continuously and lasted more than one day usually wilting and falling after 10:00 on the second morning. Flowers produced a sweet scent and nectar production as well as pollen release started when the flowers opened. The nectar volume present in the flowers was similar during the morning and increased slightly in the afternoon $\left(F_{3,216}=23.25, p<0.001\right.$, Fig. 1A $)$. Flowers isolated from the flower visitors averaged a twofold larger nectar volume in the second morning in relation to recently opened flowers (Fig. 1A). Compared with bagged flowers, it was possible to observe almost complete depletion of nectar in exposed flowers during the day, after the first sampling period early in the morning. Flowers restored some nectar volume during the second morning, which was probably due to lower temperatures during night and lack of nocturnal visitors. Most flowers had a measurable quantity of nectar but approximately $8 \%$ of the bagged flowers were empty. The concentration of nectar varied considerably in S. ferrugineus, with the lowest value occurring early in the morning on the first day and the highest peak during late afternoon $\left(F_{3,216}=17.80, p<0.001\right.$, Fig. 1B). The amount of sugar per flower increased with the life span of the flower $\left(\mathrm{F}_{3,216}=54.73\right.$, p $<0.001$, Fig. 1C).

Small insects were the most frequently recorded flower visitors ( $11.09 \pm 8.63$ visits/hour, 366 total) followed by large bees $(8.60 \pm 5.44 \mathrm{v} / \mathrm{h}, 284$ total), lepidopterans $(4.30 \pm 6.13$ $\mathrm{v} / \mathrm{h}, 142$ total), wasps $(3.12 \pm 3.44 \mathrm{v} / \mathrm{h}, 103$ total $)$ and hummingbirds $(2.76 \pm 2.74 \mathrm{v} / \mathrm{h}, 91$ total). Some groups of visitors had their visit rates influenced by the time of the day (Fig. 2). Small insects $\left(\mathrm{F}_{4,28}=3.55, \mathrm{p}=0.018\right)$ and wasps $\left(\mathrm{F}_{4,28}=11.12\right.$, $\mathrm{p}<0.001$ ) visited flowers more frequently in the middle of the day, while hummingbirds were more frequent early in the morning $\left(\mathrm{F}_{4,28}=3.34, \mathrm{p}=0.023\right)$. On the other hand, the visitation frequency of large bees $\left(\mathrm{F}_{4,28}=0.50, \mathrm{p}=0.739\right)$ and lepidopterans $\left(\mathrm{F}_{4,28}=2.05, \mathrm{p}=0.114\right)$ did not vary during the day. 

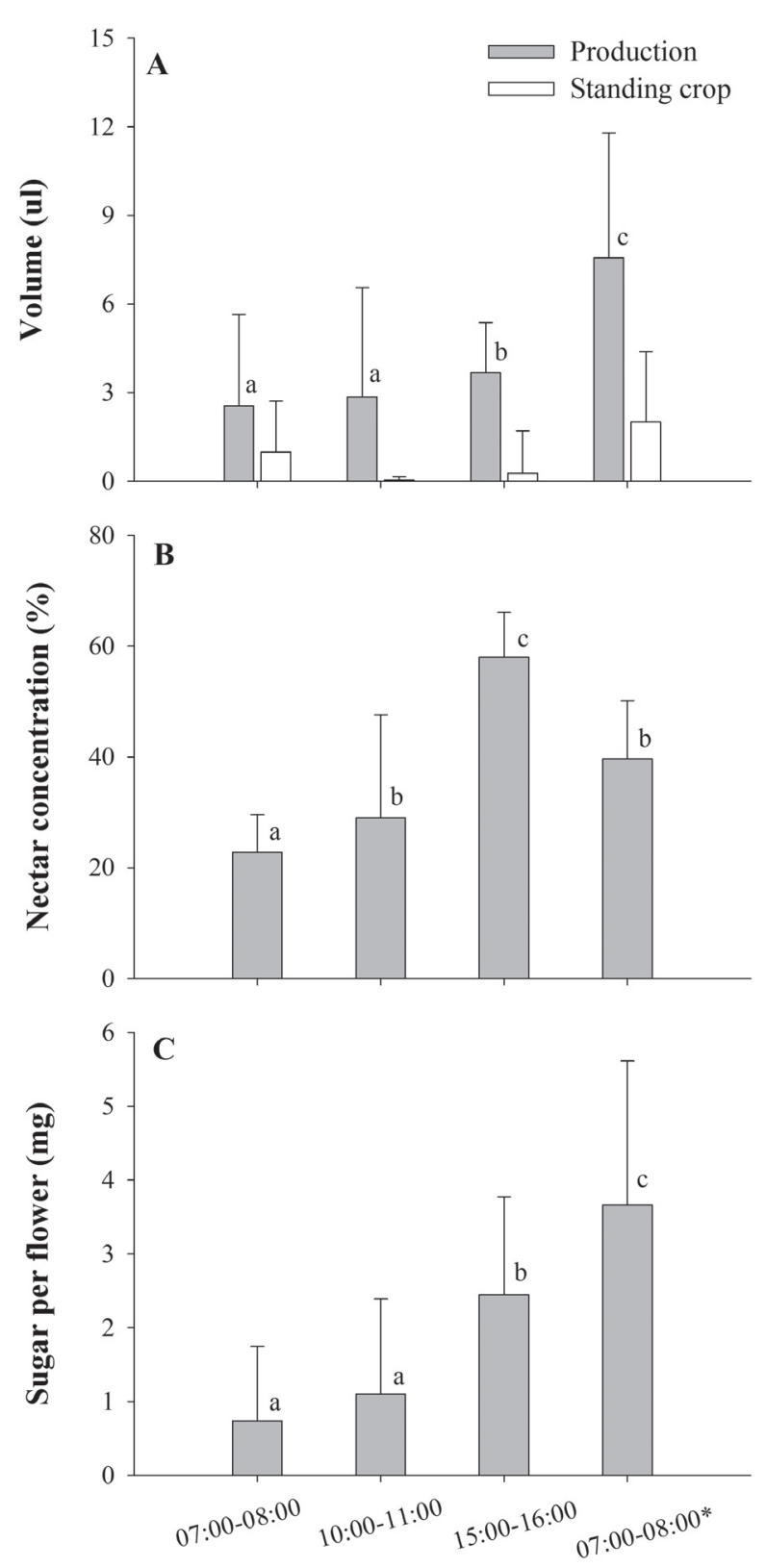

Sampling time

Figure 1. Nectar availability in Styrax ferrugineus Nees \& Mart at different sampling intervals in the cerrado of Uberlândia - MG. A. Volume of nectar in bagged flowers (production) and in flowers exposed to floral visitors (standing crop). B. Variation in nectar concentration. C. Amount of sugar per flower. At least forty flowers for each category at each time interval were sampled (maximum of five flowers for each individual at given time interval and category). Asterisk in the last time interval indicates samples from the second morning. Different letters above bars show significant differences among time intervals (ANOVA and post hoc Tukey test, $\mathrm{p}<0.05$ ).

For each visit, large bees probed $22.61 \pm 17.44$ flowers $(n=62)$, which was not significantly different $\left(\mathrm{t}_{109}=0.202, \mathrm{p}=0.84\right)$ from the hummingbirds, which probed $21.98 \pm 14.95$ flowers per visit $(n=49)$. However, the visits of large bees lasted longer than the visits of hummingbirds (bees: $135.00 \pm 125.37 \mathrm{~s}$, hummingbirds: $\left.68.08 \pm 67.09 \mathrm{~s}, \mathrm{t}_{109}=3.88, \mathrm{p}<0.001\right)$.
Of the large bees, we identified species of Xylocopa [e.g., X. hirsurtissima (Maidl 1912), X. subcyanea (Perez 1901) and $X$. frontalis (Olivier 1789)] and Bombus [e.g., B. atratus (Franklin 1913)] as the principal visitors. These bees were often buzzing their body during flower visits, and apparently collecting pollen. Among wasps, species of Pompilidae (genus Pepsis and Entypus) and Sphecidae were commonly observed. Considering the lepidopterans, butterflies of the family Hesperidae were the most common visitors. The most common hummingbirds were Amazilia fimbriata (Gmelin, 1788) with $36.3 \%$ of the visits, Eupetomena macroura (Gmelin, 1788) with $34.1 \%$ of the visits and Chlorostilbon lucidus (Shaw, 1812) with 27.3\% of the visits, while Colibri serrirostris (Vieillot, 1816) was observed only twice. Territorial behavior was observed in E. macroura and A. fimbriata with the former appearing as the hierarchically dominant species. Agonistic interactions were not limited within the hummingbirds, because they frequently repelled other visitors, especially large bees of the genus Xylocopa and Bombus. Nevertheless, territorial hummingbirds seemed to be unable to repel the majority of other insects visitors due to their high abundance, and many large bees tried insistently to visit the flowers even after being chased. During the visits, all visitors seemingly contacted the reproductive organs of the flowers, with the exceptions of small insects and hummingbirds. Pollination seemed more difficult for smaller insect visitors because they probed nectar without contacting their body to stigma, although they frequently contacted the anthers and removed pollen. Hummingbirds also frequently contacted the anthers with their bills, thus removing pollen, but since the short corolla of S. ferrugineus does not orient the hummingbird to contact its bill to stigma, pollination was not assured.

Flowering period extended from May to July during the dry cold season of the Cerrado (Fig 3). During flowering an individual could present more than 150 flowers per day but there was considerable variability and the mean flower availability per day during peak flowering was 38.1 230.0 flowers per individual (Fig. 3). Fruit-set occurred more frequently in the cross-pollination treatment and control flowers, which had a similar proportion of fruit formation (Tab. 1). Self-pollination and spontaneous self-pollination also formed fruits, but with a considerably smaller frequency. Agamospermy treatments did not set fruits. The experiment designed to infer the effect of hummingbird visits on plant reproduction showed no difference in the fruit-set between treatments $\left(t_{13}=0.322, \mathrm{p}=0.75\right)$. When hummingbirds were allowed to visit, $33.14 \pm 20.98 \%$ of flowers were converted into fruits whereas in the hummingbird exclusion treatment fruit-set was $32.86 \pm 14.95 \%$.

\section{Discussion}

Flowers of Styrax ferrugineus were visited by a broad array of visitors, mostly insects, but with a considerable number of hummingbird visits, which is comparable to 


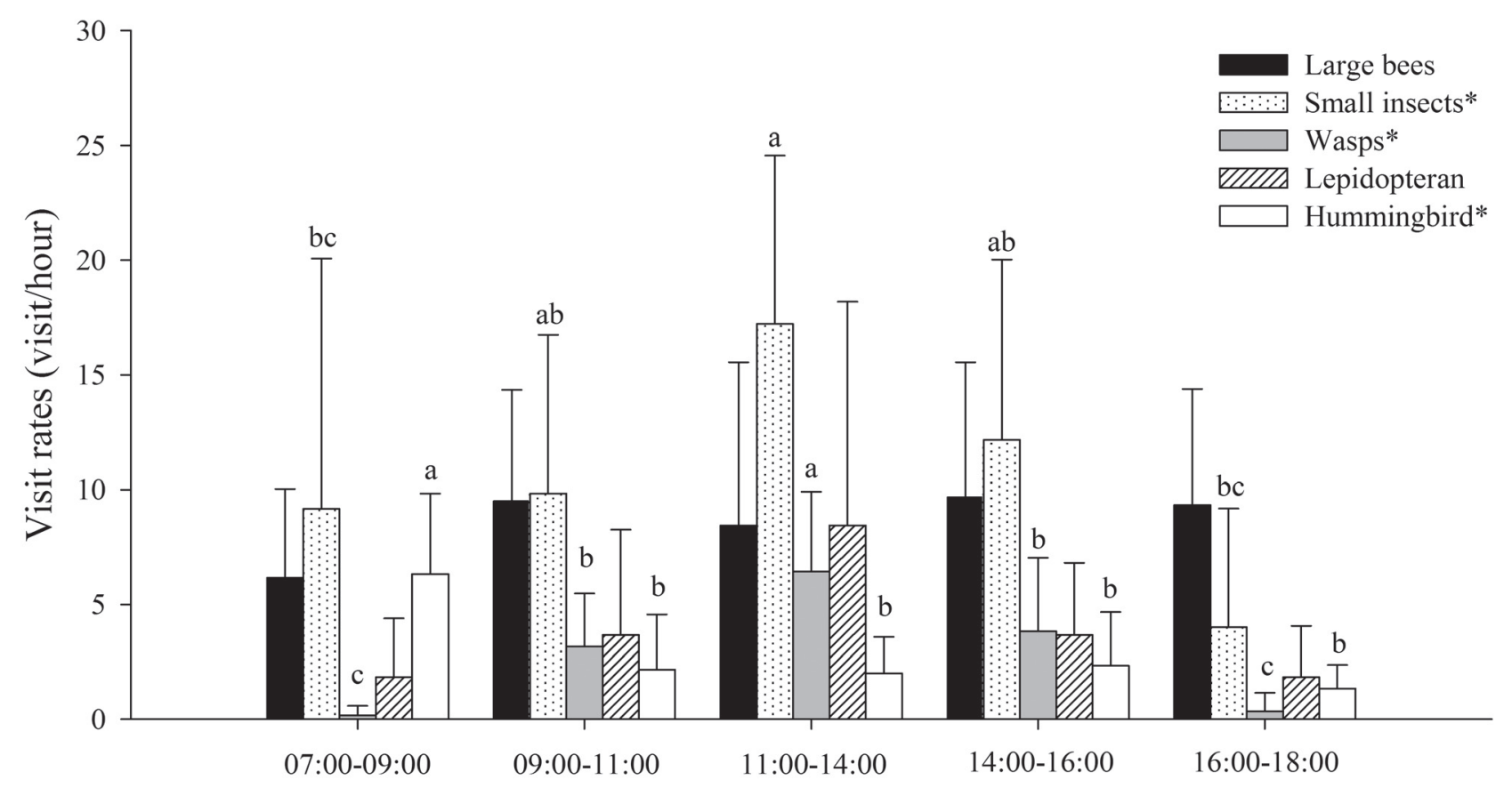

Figure 2. The frequency of different flower visitors according to time interval in Styrax ferrugineus Nees \& Mart in the cerrado of Uberlândia - MG. Asterisk indicates difference in the visitation frequency among time intervals for each visitor category (ANOVA p $<0.05$ ) and different letters above SD bars indicate significant differences among time intervals within flower visitor groups (Tukey test).

what has been observed for other important hummingbird pollinated plants in the Cerrado (e.g. Justino et al. 2012). In studies with the genus Styrax, bees and other insects are always mentioned as visitors and pollinators, but visits by birds have not been recorded (Kato \& Hiura 1999; Huang et al. 2003). Even in a previous study with S. ferrugineus from the Cerrado, visits by hummingbirds were not mentioned (Saraiva et al. 1988). In this particular case, the small sample effort devoted and/or the previous assumption of $S$. ferrugineus being a bee flower could probably account for the absence of hummingbirds in the flower visitor records. But hummingbird visits to $S$. ferrugineus are commonly observed and recorded in other studies (e.g. Gottsberger \& Silberbauer-Gottsberger 2006).

The visitation rates varied differently among groups of flower visitors and this may be related to differences in the importance of factors affecting visitation. Hummingbirds visited flowers more frequently early in the morning when the standing crop was higher, while most insect groups visited or tended to visit flowers more frequently at noon. While the visits of hummingbirds are frequently associated to nectar availability (Brown et al. 1981; Justino et al. 2012), insect visits are more influenced by the temperature than nectar availability (Brown et al. 1981). During the cold dry season in the Cerrado the temperature can be considerably low early in the morning and before dusk, which probably hindered most insect visitors. Activities of larger bees, such as carpenter and bumblebees, seem to be less affected by temperature (as in Brown et al. 1981) and these insects were active all day long. Visits of hummingbirds were similar to visits of large bees when considering the number of flowers probed, but considering the duration of visits, large bees spent considerably more time in the flowers. Along with the behavioral differences between the two groups in handling flowers, bees may have also spent more time in order to collect pollen. In a previous study, Saraiva et al. (1988) stated that the only resource offered by $S$. ferrugineus to its visitors was nectar. However, large bees also seemed to actively collect pollen grains, which was confirmed by their buzzing behavior and by the presence of $S$. ferrugineus pollen grains in the nests of species of Xylocopa in the studied region (Silva 2009).

The population of S. ferrugineus in Uberlândia presented a considerable number of flowers on a daily basis for a relatively short period, of nearly two months. This type of mass-flowering pattern in trees is frequently associated to the attraction of a variety of generalist insects (Johnson \& Steiner 2000, Maruyama et al. 2010). The hand pollination treatment showed that $S$. ferrugineus produced more fruits after cross-pollination than self-pollination and that there was no pollen limitation since control flowers presented a similar fruit-set when compared to hand cross-pollination. The results of the pollination experiments in this study contrast significantly with the results of Saraiva et al. (1988), who did not record fruit formation after self-pollination. Differences in the reproductive biology among populations could be responsible for this inconsistency.

Even though its flowers are considered primarily bee flowers with an association of other insect groups, hummingbird visits were frequent in S. ferrugineus. The effect 


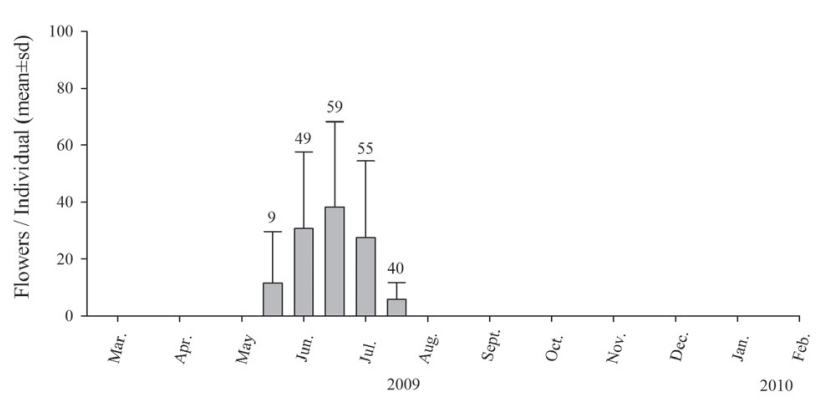

Figure 3. Flowering phenology of Styrax ferrugineus Nees \& Mart from March 2009 to February 2010 in the cerrado of Uberlândia - MG. Values above bars indicate the number of flowering individuals in the sampled area.

Table 1. Results of hand pollination experiments for Styrax ferrugineus Nees \& Mart, in a cerrado of Uberlândia-MG. Results for a Corumbataí-SP study (Saraiva et al. 1988) are shown for comparison.

\begin{tabular}{lccc}
\hline Pollination treatment & Fruit set (n) & $\%$ & $\begin{array}{c}\text { Saraiva et al. } 1988 \\
(\%)\end{array}$ \\
\hline Cross-pollination & $25(61)$ & 40.9 & 46.0 \\
Self-pollination & $9(62)$ & 14.5 & 0.0 \\
Spontaneous self-pollination & $2(50)$ & 4.0 & 0.0 \\
Agamospermy & $0(57)$ & 0.0 & 0.0 \\
Natural pollination & $26(62)$ & 41.9 & 35.0 \\
\hline
\end{tabular}

that an illegitimate flower visitor (nectar robbers or thieves) has on plant reproduction can be negative, neutral or even positive (Maloof \& Inouye 2000; Lara \& Ornelas 2001; Fumero-Cabán \& Meléndez-Ackerman 2007). Plants may show adaptation in order to restrict the access to flower resource to those visitors which act as efficient pollinators (Castellanos et al. 2004). But attraction of a larger, generalized spectrum of pollinators could be advantageous when considering fluctuations in pollinator availability over time (Waser et al. 1996). In our case, the exclusion of hummingbirds did not change the fruit-set, which means that hummingbird visits apparently had no perceptible effect on plant reproduction. The effect nectar robbers have on plant reproduction depends of many factors, such as the type of pollinator, plant biology, the proportion of nectar removed by robbers and the resources available in the environment (Maloof \& Inouye 2000), and these variables may be similar in the case of nectar thieves. Due to the morphological mismatch, hummingbirds probably have a small direct contribution to $S$. ferrugineus reproduction, as observed for other insect pollinated plants in the Cerrado (Oliveira \& Gibbs 1994). On the other hand, their frequent visits probably remove significant amounts of nectar. By stealing nectar, nectar robbers and thieves could induce legitimate pollinators to visit more flowers or individuals, thus increasing pollination rates (Maloof \& Inouye 2000). Whether this is the case with S. ferrugineus, we have no clear evidence. But, when considering our sample unit (branch), fruit-set did not increase.
The great variability in nectar volume and concentration observed in $S$. ferrugineus probably resulted from the different environmental conditions experienced by the flowers during anthesis. Temperature and humidity can have considerable influence on nectar properties, especially for flowers with short and open corollas (Galetto \& Bernadello 2005). Styrax ferrugineus flowers during the dry and cold season in the Cerrado, when temperatures can vary considerably during the day. The apparently constant nectar secretion observed, combined with the nectar evaporation due to increasing temperatures during the midafternoon increase nectar concentrations, while colder nights interrupt nectar evaporation and may help to dilute the nectar. The presence of empty flowers, as previously observed by Saraiva et al. (1988), had been interpreted as a mechanism to reduce energy expenditure in nectar production and/or to increase the number of flowers a pollinator visits (Feinsinger 1978). If a pollinator, finding several empty flowers within the same plant, gives up on searching for nectar in additional flowers and flies to the next co-specific plant, then the presence of empty flowers could increase outcrossing rates. In contrast, if a pollinator responds to the presence of empty flowers by visiting more flowers within the same individual, the result would be the opposite, increasing the rate of self-pollination. How the presence of empty flowers in S. ferrugineus affects pollinator behavior and consequently plant reproduction remains to be investigated.

Nectar variation and even empty flowers may also affect foraging behavior of hummingbirds. The agonistic territorial defense was restricted to other hummingbirds and large, high-energy-demanding bees. Since flower choice and feeding behavior of hummingbirds are strongly related to nectar availability (Justino et al. 2012), territorial behavior was observed mostly early in the morning, when there was a higher nectar standing crop. This contrasts with truly ornithophilous plants, such as Palicourea rigida Kunth in cerrado, which receive frequent visits from hummingbirds and are defended all day long (Justino et al. 2012).

The reason why frequent hummingbird visits did not affect plant reproduction could be a consequence of many factors. First, hummingbird visits were frequent only early in the morning, leaving the flowers free for the rest of day. Second, even when frequent, it is unlikely that hummingbird visits removed all of the nectar in the flowers of $S$. ferrugineus, which produces a large amount of flowers on a daily basis. Third, although hummingbirds removed pollen by contacting the anthers, they probably had little effect on the male component of reproductive success, because $S$. ferrugineus flowers produced massive quantities of pollen grains. Finally, the most constant and probably most efficient pollinators, which were the large bees, were after not only nectar but also pollen, which may limit the effect of hummingbirds in reducing the attractiveness of the flowers to the pollinators. 
The effect of illegitimate visitors in pollination is complex and depends on many factors (Maloof \& Inouye 2000), and this may explain the absence of a perceptible effect of hummingbird visits on $S$. ferrugineus fruit-set. In this sense, more studies seeking to understand the ecological consequence of hummingbird visits on non-ornithophilous plants would be interesting, especially in ecosystems where this seems to be common, such as in the Cerrado region (Oliveira \& Gibbs 1994; Araujo \& Sazima 2003). From the perspective of the plant (fruit-set), the effect of hummingbird visits was minimal and imperceptible. However, these visits may be important for hummingbirds, which specialize in nectar feeding and the contribution of non-ornithophilous flowers to their persistence cannot be neglected.

\section{Acknowledgements}

We are grateful to Maria Margarida M. D. Silva for field support. We thank the CCPIU administration for the permission to carry out studies in its reserve. This study was supported by CNPq and FAPEMIG with scholarships and funding. We thank Felipe W. Amorim, Leandro Freitas, Francielle P. Araújo and Amanda F. Cunha for comments on previous versions of the manuscript and Marcela Yamamoto, Solange C. Augusto and Kleber Del-Claro for helping with insect identification.

\section{References}

Araujo, A.C \& Sazima, M. 2003. The assemblage of flowers visited by hummingbirds in the "capões" of Southern Pantanal, Mato Grosso do Sul, Brazil. Flora 198: 427-435.

Brown, J.H.; Kodric-Brown, A.; Whitham, T.G. \& Bond, H.W. 1981. Competition between hummingbirds and insects for the nectar of two species of shrubs. The Southwestern Naturalist 26: 133-145.

Castellanos, M.C.; Wilson, P. \& Thomson, J.D. 2004. 'Anti-bee' and 'probird' changes during the evolution of hummingbird pollination in Penstemon flowers. Journal of Evolutionary Biology 17: 876-885.

Feinsinger, P. 1978. Ecological interactions between plants and hummingbirds in a successional tropical community. Ecological Monographs 48: 269-287.

Fritsch, P.W. 1999. Phylogeny of Styrax based on morphological characters, with implications for biogeography and infrageneric classification. Systematic Botany 24: 355-378.

Fumero-Cabán, J.J. \& Meléndez-Ackerman, E.J. 2007. Relative pollination effectiveness of floral visitors of Pitcairnia angustifolia (Bromeliaceae). American Journal of Botany 94(3): 419-424.
Galleto, L. \& Bernardello, G. 2005. Nectar. Pp. 261-313. In: Dafni, A.; Kevan, P.G. \& Husband, B.C. (eds.) Pratical pollination biology. Ontario, Cambridge, Enviroquest Ltd.

Gottsberger, G. \& Silberbauer-Gottsberger, I. 2006. Life in the Cerrado: a south American tropical seasonal ecosystem II. Ulm, Reta Verlag.

Huang Y.; Fritsch, P.W. \& Shi, S. 2003. A revision of the imbricate group of Styrax series Cyrta (Styracaceae) in Asia. Annals of Missouri Botanical Garden 90(4): 491-553.

Inouye, D.W. 1980. The terminology of floral larceny. Ecology 61: 12511253.

Johnson, S.D. \& Steiner, E. 2000. Generalization versus specialization in plant pollination systems. Trends in Ecology and Evolution 15: 140-143.

Justino, D.G.; Maruyama, P.K. \& Oliveira, P.E. 2012. Floral resource availability and hummingbird territorial behaviour on a Neotropical savanna shrub. Journal of Ornithology, in press.

Kato, E. \& Hiura, T. 1999. Fruit set in Styrax obassia (Styracaceae): the effect of light availability, display size, and local floral density. American Journal of Botany 86: 495-501.

Lara, C. \& Ornelas, J.F. 2001. Nectar 'theft' by hummingbird flower mites and its consequences for seed set in Moussonia deppeana. Functional Ecology 15: 78-84.

Maloof, J. \& Inouye, D.W. 2000. Are nectar robbers cheaters or mutualists? Ecology 81: 2651-2661.

Maruyama, P.K.; Amorim, F.W. \& Oliveira, P.E. 2010. Night and day service: distyly and mixed pollination system in Faramea cyanea (Rubiaceae). Flora 205: 818-824.

Muchhala, N. 2006. The pollination biology of Burmeistera (Campanulaceae): specialization and syndromes. American Journal of Botany 93(8): 1081-1089.

Nakajima, J.N. \& Monteiro, R. 1986. Estudos fitogeográficos com espécies de Styrax L. (Styracaceae) dos cerrados brasileiros. Eugeniana 12: 3-10.

Oliveira, P.E. \& Gibbs, P.E. 1994. Pollination and breeding systems of some Vochysia species (Polygalales-Vochysiaceae) in Central Brazil. Journal of Tropical Ecology 10: 509-522.

Rojas, R. \& Ribon, R. 1997. Guilda de aves em Bowdichia virgilioides (Fabaceae: Faboideae) em área de cerrado de Furnas, Minas Gerais. Ararajuba 52: 189-194.

Roubik, D.W. 1982. The ecological impact of nectar-robbing bees and pollinating hummingbirds on a tropical shrub. Ecology 63: 354-360.

Saraiva, L.C.; Cesar, O. \& Monteiro, R. 1988. Biologia da polinização e sistema de reprodução de Styrax camporum Pohl e S. ferrugineus Nees et Mart. (Styracaceae). Revista Brasileira de Botânica 11: 71-80.

Silva, C.I. 2009. Distribuição espaço-temporal de recursos florais utilizados por espécies de Xylocopa (Hymenoptera, Apidae) e interações com plantas do cerrado sentido restrito no Triângulo Mineiro. Tese de Doutorado. Universidade Federal de Uberlândia, Uberlândia.

Stiles, F.G. 1981. Geographical aspects of bird-flower coevolution, with particular reference to Central America. Annual Missouri Botanical Garden 68: 323-351.

Waser, N.M.; Chittka, L.; Price, M.V.; Williams, N.M. \& Ollerton, J. 1996. Generalization in pollinations systems, and why it matters. Ecology 77: 1043-1060.

Zar, J.H. 1999. Biostatistical analysis. 4 ed. New Jersey, Prentice-Hall. 